\title{
Validation of the Arabic version of the SCOFF questionnaire for the screening of eating disorders
}

\author{
A. Aoun, ${ }^{1,3}$ J. Azzam, ${ }^{2}$ F. El Jabbour, ${ }^{2}$ S. Hlais, ${ }^{2}$ D. Daham, ${ }^{2}$ C. El Amm, ${ }^{2}$ K. Honein ${ }^{2}$ and P. Déchelotte ${ }^{3}$
}

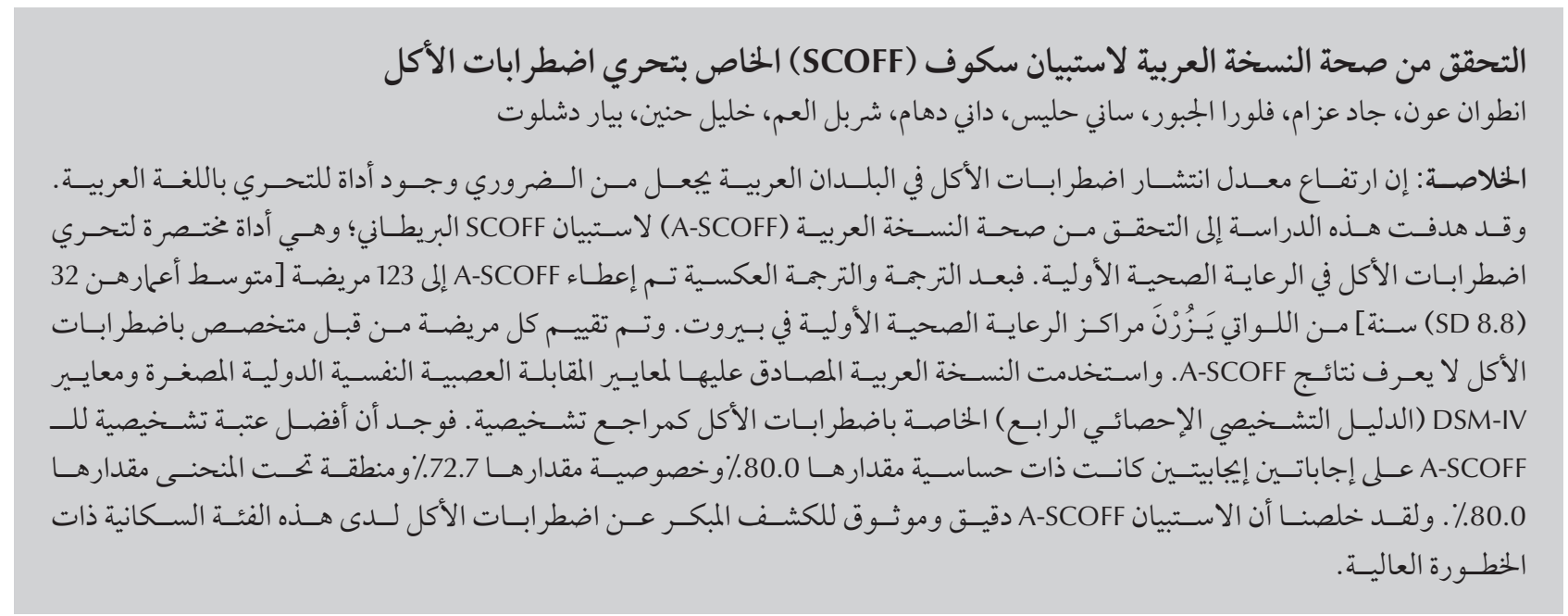

ABSTRACT The high prevalence of eating disorders in Arab countries indicates a need for an Arabic language screening tool. This study aimed to validate an Arabic version (A-SCOFF) of the British SCOFF questionnaire, a brief tool for the screening of eating disorders in primary health care. After translation and back-translation the A-SCOFF was given to 123 female patients [mean age 32 (SD 8.8) years] visiting primary health-care centres in Beirut. Each patient was evaluated by an eating disorders specialist blinded to A-SCOFF results. The validated Arabic version of the Mini International Neuropsychiatric Interview and the DSM-IV criteria for eating disorders were used as diagnostic references. The best diagnostic threshold for the A-SCOFF was found to be at 2 positive answers with a sensitivity of $80.0 \%$, a specificity of $72.7 \%$ and an area under the curve of $80.0 \%$. The A-SCOFF questionnaire is accurate and reliable for the early detection of eating disorders in this high-risk population.

Validation de la version en langue arabe du questionnaire SCOFF pour le dépistage des troubles alimentaires

RÉSUMÉ La forte prévalence des troubles alimentaires dans les pays arabes indique la nécessité d'un outil de dépistage en langue arabe. La présente étude visait la validation de la version en langue arabe (SCOFF-A) du questionnaire SCOFF britannique, un outil succint pour le dépistage des troubles alimentaires en soins de santé primaires.Aprèstraduction etrétrotraduction, lequestionnaireSCOFF-Aaétéadministréà123 patientes(âgemoyen 32 ans [ET 8,8 ans])consultantdansdescentresdesoins desantéprimairesàBeyrouth. Chaquepatienteaétéévaluée par un spécialiste des troubles alimentaires n'ayant pas eu connaissance des résultats au questionnaire SCOFF-A. La version en langue arabe validée du bref entretien neuropsychiatrique Mini International Neuropsychiatric Interview et les critères du DSM-IV pour les troubles alimentaires ont été utilisés en tant que références diagnostiques. Le meilleur seuil diagnostique pour le questionnaire SCOFF-A a été déterminé à deux réponses positives avec une sensibilité de 80,0 \%, une spécificité de 72,7 \% et une aire sous la courbe de 80,0\%. Le questionnaire SCOFF-A est précis et fiable pour le dépistage précoce des troubles alimentaires dans cette population à haut risque.

${ }^{7}$ Notre Dame University, Zouk Mosbeh, Lebanon. ${ }^{2}$ Saint Joseph University, Beirut, Lebanon. ${ }^{3}$ INSERM U1073, Rouen University and Rouen University Hospital, Rouen, France (Correspondence to A. Aoun: aaoun@ndu.edu.lb).

Received: 04/08/14; accepted: 10/03/15 


\section{Introduction}

Eating disorders constitute a growing health problem with multifactorial etiology, affecting adolescents and young adults everywhere including Arab countries $(1,2)$. These disorders are characterized by harmful eating behaviours and unhealthy concerns about body weight and shape. The most common eating disorders are anorexia nervosa (fear of gaining weight, self-starvation, and a distorted view of body image), bulimia nervosa (recurrent episodes of binging followed by inappropriate purging behaviour) and eating disorder not otherwise specified (EDNOS) [similar symptoms with anorexia nervosa and bulimia nervosa but not fulfilling all the diagnostic criteria of the Diagnostic and statistical manual of mental disorders, 4th edition (DSM-IV)]. The DSM-IV is internationally considered as the gold standard reference for psychiatric disorders. It contains criteria defining the different types of eating disorders (3).

The worldwide prevalence of eating disorders among adolescents is around $10 \%$, with a peak of occurrence from 15 to 19 years old (4). It has been estimated that $0.3-2.2 \%$ of young females in developed countries suffer from anorexia nervosa (5-9) and $1-2 \%$ from bulimia nervosa $(5,6,8)$. Mortality from anorexia nervosa has been estimated to be as high as $5.0 \%(10)$. In the last decade, studies indicate a gradual increase of abnormal eating behaviours in less developed countries too $(10,11)$. Al-Subaie, who examined dieting behaviour using the Eating Disorders Inventory (EDI), found that $15.9 \%$ of schoolgirls from grades 7 to 11 in Saudi Arabia scored positively for the thinness subscale (12). Using the Eating Attitudes Test (EAT-26) Nobakht and Dezhkam reported a prevalence of $0.9 \%$ for anorexia nervosa, 3.2\% for bulimia nervosa and 6.6\% for EDNOS among schoolgirls in the Islamic Republic of Iran (13). One of the possible risk factors for eating disorders in countries of the WHO Eastern Mediterranean Region is sociocultural changes including modernization and media pressure which impose new standards of female beauty. Another factor could be living in conflict situations. Aoun et al. showed that stress during wartime was associated with an increased risk of eating disorders among a population of university students in Beirut, Lebanon (14).

An effective screening tool is therefore needed for early detection and immediate intervention for eating disorders in Arab countries (15). However, the commonly used screening tools such as the EAT $(16,17)$, EDI (18), the Eating Disorder Examination Questionnaire (EDE-Q) (19) and Bulimic Inventory Test Edinburgh (BITE) (20) are often lengthy and time-consuming, and they can be difficult to interpret for a non-specialist $(21,22)$. So far, none of these tests has been clearly recommended. Recently, a new screening tool, the SCOFF questionnaire, was developed in the United Kingdom to overcome these limitations (23). The SCOFF is a brief and easily memorized instrument consisting of 5 questions designed to screen for eating disorders (23). The SCOFF questionnaire is considered to be effective as a screening tool in its British (24), Catalan (25), Finnish (26), French (27), Italian (28), Spanish (29) and United States (30) versions.

A simple Arabic language screening test such as the SCOFF questionnaire would be very useful for detecting eating disorders in primary-care settings in Arab countries. The aim of this study was to assess the validity of the Arabic language version of the SCOFF (ASCOFF) for the detection of eating disorders in primary health-care settings.

\section{Methods}

\section{Translation}

Five health-care professionals and 2 experts in the field of translation were involved. The original British version of the SCOFF was translated into Arabic language based on international criteria. Back translation to English was performed independently and differences were solved by agreement. A pilot study was done on 7 women to check the interpretation and comprehension of each item of the final Arabic form of the questionnaire.

\section{Participants}

The present study was carried out from October 2008 to April 2009. Participants were randomly selected from 2 primary health-care centres in Beirut, Lebanon, that are known for their advanced activity in the field of nutrition and psychiatry. The patients visiting these centres come all regions of Lebanon and are not necessarily of Lebanese nationality. The exclusion criteria were male sex and age under 15 or over 55 years.

The study received approval from the local research ethics committee. Women were approached individually to participate in the survey. Written consent was obtained from each woman on a form explaining the procedure of the study and the participant's rights. The questionnaires were answered anonymously. Personal information consisted of date of birth, nationality, religion, family status, socioeconomic status and work. The consultation lasted around 15 minutes during which the participant first completed the A-SCOFF questionnaire on her own and then was evaluated by an eating disorders specialist blinded to the A-SCOFF results. The validated Arabic version of the Mini International Neuropsychiatric Interview (MINI) and DSM-IV criteria for eating disorders were employed as diagnostic references.

\section{Measures}

The SCOFF questionnaire is a simple 5-question test devised for use to assess the possible presence of an eating disorder. The S in SCOFF stands for "sick" (to vomit). The $\mathrm{O}$ denotes "one stone" 
of weight (i.e. $6.35 \mathrm{~kg}$ ). The letters C, $\mathrm{F}$ and $\mathrm{F}$ stand for "control", "fat" and "food" respectively. The SCOFF can be both self-and hetero-administered and the sensitivity and specificity have been found acceptable at a threshold of 2. In our study, the A-SCOFF was self-administered by the patients.

The MINI is a short, structured diagnostic interview, developed jointly by psychiatrists and clinicians, according to the DSM-IV. It was designed to meet the need for a short but accurate structured psychiatric interview. The validated Arabic version of the MINI, together with DSM-IV criteria for eating disorders, were used as the gold standard for a diagnosis of eating disorder.

\section{Statistical analysis}

The validity of the A-SCOFF was assessed by calculating the sensitivity and specificity for all possible screening cut-off points. Sensitivity refers to the proportion of people with disease who have a positive test result. Specificity refers to the proportion of people without disease who have a negative test result. The receiver operating characteristic (ROC) displays the trade-off between sensitivity and specificity for each cutoff value. An ideal cut-off might give the test the highest possible sensitivity with the lowest possible false positive rate (i.e. highest specificity). This is the point lying geometrically closest to the topleft corner of the graph (where the ideal cut-off value with $100 \%$ sensitivity and specificity would be plotted). The area under the ROC curve can be used to estimate the accuracy (31). Cronbach alpha scale coefficient was computed to assess reliability, 0 being the minimum and 1 the maximum. Principal component analysis was run to evaluate structure validity. All analyses were performed using SPSS for Windows, version 16, and Stata, version 10. A 2-tailed $P$-value of $\leq 0.05$ was taken to indicate statistical significance.

\section{Results}

A total of 123 women were recruited from primary health-care settings and all participated in the study. The sociodemographic profile of the women showed that $91.1 \%$ were Lebanese, $63.4 \%$ were married, $43.9 \%$ were unemployed and $60.2 \%$ had relatively low monthly income (US\$ < 1000) (Table 1).

Based on DSM-IV criteria, 28.0\% of the participants were diagnosed as suffering from eating disorders (1 case of anorexia nervosa, 14 cases of bulimia nervosa and 20 cases of EDNOS), while the A-SCOFF questionnaire showed that $42.3 \%$ of the participants were at high risk of eating disorders.
Cronbach alpha scale reliability coefficient for the A-SCOFF was 0.43 . Table 2 summarizes the sensitivity and specificity for different cut-off points of the SCOFF questionnaire with their respective confidence intervals $(\mathrm{CI})$. The best SCOFF cut-off point was 2 .

The receiver operating characteristic (ROC) curve (Figure 1) shows an optimal threshold of 2 or more positive answers. The area under the curve was around 0.79 (95\% CI: 0.68-0.85).

At the cut-off score of 2 , the total questionnaire showed good sensitivity of $80.0 \%$ and specificity of $72.7 \%$ for eating disorders in all age groups (Table 3). When the data were analysed for bulimia nervosa and EDNOS separately, a higher sensitivity and specificity

\begin{tabular}{|c|c|c|}
\hline Variable & No. of participants & $\%$ \\
\hline \multicolumn{3}{|l|}{ Age (years) } \\
\hline $15-25$ & 37 & 30.1 \\
\hline $26-35$ & 41 & 33.3 \\
\hline $36-45$ & 38 & 30.9 \\
\hline $46-55$ & 7 & 5.7 \\
\hline \multicolumn{3}{|l|}{ Nationality } \\
\hline Lebanese & 112 & 91.1 \\
\hline Iraqi & 5 & 4.1 \\
\hline Other & 6 & 4.9 \\
\hline \multicolumn{3}{|l|}{ Religion } \\
\hline Christian & 96 & 78.0 \\
\hline Muslim & 26 & 21.1 \\
\hline Other & 1 & 0.8 \\
\hline \multicolumn{3}{|l|}{ Family status } \\
\hline Married & 78 & 63.4 \\
\hline Single & 40 & 32.5 \\
\hline Widowed & 2 & 1.6 \\
\hline Other & 3 & 2.4 \\
\hline \multicolumn{3}{|c|}{ Monthly income (US\$) } \\
\hline$<400$ & 15 & 12.2 \\
\hline 400-1000 & 59 & 48.0 \\
\hline$>1000$ & 38 & 30.9 \\
\hline No response & 11 & 8.9 \\
\hline \multicolumn{3}{|l|}{ Employed } \\
\hline Yes & 69 & 56.1 \\
\hline No & 54 & 43.9 \\
\hline
\end{tabular}




\begin{tabular}{|c|c|c|c|c|}
\hline \multirow{2}{*}{$\begin{array}{l}\text { Screening threshold } \\
\text { (positive answers) }\end{array}$} & \multicolumn{2}{|c|}{ Sensitivity } & \multicolumn{2}{|c|}{ Specificity } \\
\hline & $\%$ & $95 \% \mathrm{Cl}$ & $\%$ & $95 \% \mathrm{Cl}$ \\
\hline 1 & 91.4 & 77.6-97.0 & 42.1 & $32.3-52.5$ \\
\hline 2 & 80.0 & $64.1-90.0$ & 72.7 & $62.6-80.9$ \\
\hline 3 & 34.3 & $20.8-50.8$ & 92.0 & 84.5-96.1 \\
\hline 4 & 14.3 & $7.0-30.3$ & 99.9 & 94.8-100 \\
\hline
\end{tabular}

$C l=$ confidence interval.

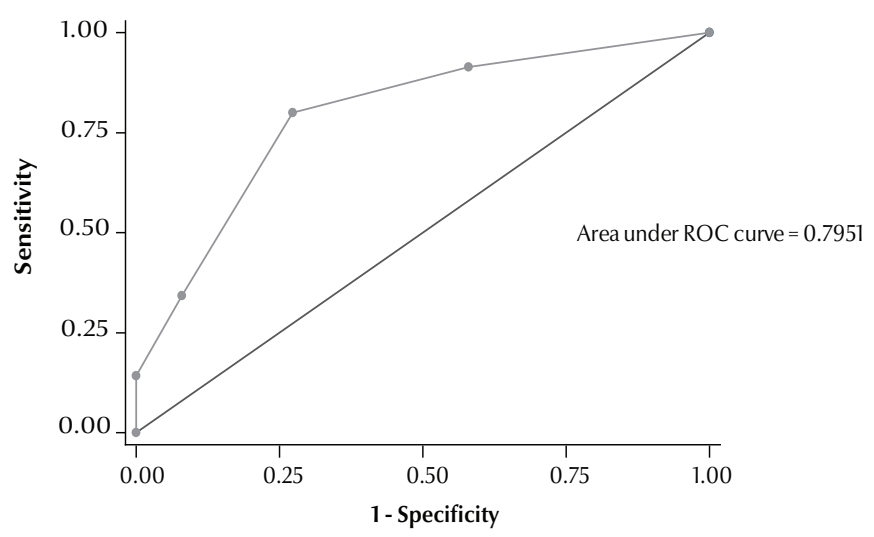

Figure 1 Area under the receiver operating characteristics curve for the Arabic version of the SCOFF screening questionnaire for eating disorders

\begin{tabular}{|c|c|c|}
\hline \multicolumn{3}{|c|}{$\begin{array}{l}\text { Table } 3 \text { Results of the Arabic version of the SCOFF screening questionnaire } \\
\text { (A-SCOFF), with a cut-off of } 2 \text { points, compared with the clinical diagnosis of } \\
\text { eating disorders based on MINI and DSM-IV criteria as the gold standard in a } \\
\text { sample of } 123 \text { women }\end{array}$} \\
\hline \multirow[t]{3}{*}{ A-SCOFF results } & \multicolumn{2}{|c|}{ Clinical diagnosis (MINI and DSM-IV criteria) } \\
\hline & Eating disorder & No eating disorder \\
\hline & No. & No. \\
\hline Positive $(\geq 2)$ & 28 & 24 \\
\hline Negative & 7 & 64 \\
\hline Total & 35 & 88 \\
\hline
\end{tabular}

MINI = Mini International Neuropsychiatric Interview; DSM-IV= Diagnostic and statistical manual of mental disorders, 4th edition.

of $91.7 \%$ and $77.3 \%$ respectively were found for the 15-25 years age group [data not shown].

Finally, principal component analysis generated 1 factor that explained $31 \%$ of the variability in the 5 questions (KaiserMeyer-Olkin value $=0.587>0.5$, Barlett test of sphericity $P=0.007$, which shows the appropriateness of principal component analysis in our case). This factor

\section{Discussion}

TheSCOFF questionnaireis a quick and easy to administer tool that can be used in screening for eating disorders and has been well studied before (23). The original British SCOFF was translated and validated in Finland (26), France (27), Italy (28), Spain $(25,29)$ and the United States (30). This is the first study in which the SCOFF questionnaire was evaluated in Arabic language in women in primary health-care settings.

The best A-SCOFF cut-off point (2 positive answers) that combined good sensitivity and specificity is similar to those considered in other studies or set by the original authors of the questionnaire (32,33). Our results concerning sensitivity and specificity are consistent with previous studies done in the same research frame $(28,32,33)$.

In our study, $28.0 \%$ of the participants suffered from eating disorders based on the DSM-IV criteria. This relatively high value may be due to self-selection by patients, as the studied primary health-care centres are known for their special interest in the field of nutrition and psychiatry. The SCOFF questionnaire tends to show considerably better results in high-risk populations. The validation of the Spanish and the Finnish version of the SCOFF questionnaire in clinical settings showed excellent validity figures compared with their validation among students and healthy populations (28-31).

This study had several limitations. The participants were recruited only from 2 primary health-care centres, located in Beirut and known for their interest in psycho-nutrition. Nevertheless the SCOFF questionnaire is expected to be used in populations with a high risk of eating disorders (19), similar to the patients in our sample. It should be note that despite the high prevalence of eating disorders (35/123), the prevalence of anorexia nervosa was relatively low in our sample (1/123). Another limitation is related to the fact that we 


\begin{tabular}{|c|c|c|}
\hline British SCOFF equivalent items & A-SCOFF item & Factor 1 \\
\hline $\begin{array}{l}\text { Do you make yourself Sick because you feel } \\
\text { uncomfortably full? }\end{array}$ & هل تتعمّدين التقيؤ لأنّك تشعرين بتخمة مزعجة ؟ & 0.52 \\
\hline $\begin{array}{l}\text { Do you worry you have lost Control over how } \\
\text { much you eat? }\end{array}$ & هل تقلقين من فقدان السيطرة على كمية الطعام التي تتناولينها؟ & 0.75 \\
\hline $\begin{array}{l}\text { Have you recently lost more than One stone in a } \\
3 \text { month period? }\end{array}$ & هل فقدت مؤخّر اً أكثر من 35.6 كيلو غرامات خلال فترة تمتدّ على 3 أشهر؟ & 0.30 \\
\hline $\begin{array}{l}\text { Do you believe yourself to be Fat when others } \\
\text { say you are too thin? }\end{array}$ & هل تعتقدين أنــك سمينة بينما يقول الآخرون أنــك نحيفة جداً ج & 0.60 \\
\hline Would you say that Food dominates your life? & هل يمكنك القول أنّ الطعام يسيطر على حياتك ؟ & 0.51 \\
\hline
\end{tabular}

excluded men from the study because there are insufficient data about the validity of the SCOFF among men.

The use of short and easy-to-administer screening tests that do not require a specialist's interpretation saves both time and effort and enables more time to be dedicated to a subsequent more specialized assessment stage. The results of this study suggest that the A-SCOFF questionnaire could be useful in primary-care settings, enabling the detection of women at risk for eating disorders among community samples. Therefore, the A-SCOFF could be adopted by non-specialists as a means of raising their index of suspicion of a likely case of eating disorders. This is consistent with the findings of other authors in different contexts (33). These issues are relevant to both the early detection of eating disorders and the monitoring of treatment course.

This is the first validation of the Arabic version of the SCOFF questionnaire in a particular medical setting. Care should be taken in extrapolating the results to the entire Arabic population.

In conclusion, the Arabic language version of the SCOFF questionnaire showed good psychometric properties for the detection of eating disorders in primary care and it deserves to be used in at-risk populations. Due to the lack of general population-based studies on eating disorders in the Eastern Mediterranean Region, it is difficult to estimate the real prevalence of eating disorders in Arab populations and the effectiveness of the A-SCOFF in the general population. Further studies should be undertaken in order to establish the ideal target population of this tool.

\section{Acknowledgements}

\section{Funding: None.}

Competing interests: None declared.

\section{References}

1. Martínez-González MA, Gual P, Lahortiga F, Alonso $\mathrm{Y}$, de Irala-Estévez J, Cervera S. Parental factors, mass media influences, and the onset of eating disorders in a prospective population-based cohort. Pediatrics. 2003 Feb;111(2):315-20. PMID:12563057

2. Makino M, Tsuboi K, Dennerstein L. Prevalence of eating disorders: a comparison of Western and non-Western countries. MedGenMed. 2004;6(3):49. PMID:15520673

3. Diagnostic and statistical manual of mental disorders. 4th ed. Text revision. Washington (DC): American Psychiatric Association; 2000

4. Bulik CM, Reba L, Siega-Riz AM, Reichborn-Kjennerud T. Anorexia nervosa: definition, epidemiology, and cycle of risk. Int J Eat Disord. 2005;37 Suppl:S2-9, discussion S20-1. PMID:15852310

5. Hoek HW. Incidence, prevalence and mortality of anorexia nervosa and other eating disorders. Curr Opin Psychiatry. 2006 Jul;19(4):389-94. PMID:16721169

6. Hsu LK. Epidemiology of the eating disorders. Psychiatr Clin North Am. 1996 Dec;19(4):681-700. PMID:8933602

7. Keski-Rahkonen A, Hoek HW, Susser ES, Linna MS, Sihvola E, Raevuori A, et al. Epidemiology and course of anorexia nervosa in the community. Am J Psychiatry. 2007 Aug;164(8):1259-65. PMID:17671290

8. Hudson JI, Hiripi E, Pope HG Jr, Kessler RC. The prevalence and correlates of eating disorders in the National Comorbidity Survey Replication. Biol Psychiatry. 2007 Feb 1;61(3):348-58. PMID:16815322

9. Steinhausen HC. The outcome of anorexia nervosa in the 20th century. Am J Psychiatry. 2002 Aug;159(8):1284-93. PMID:12153817

10. Gunewardene A, Huon GF, Zheng R. Exposure to westernization and dieting: a cross-cultural study. Int J Eat Disord. 2001 Apr;29(3):289-93. PMID:11262507

11. Huon GF, Mingyi Q, Oliver K, Xiao G. A large-scale survey of eating disorder symptomatology among female adolescents in the People's Republic of China. Int J Eat Disord. 2002 Sep;32(2):192-205. PMID:12210662

12. Al-Subaie AS. Some correlates of dieting behavior in Saudi schoolgirls. Int J Eat Disord. 2000 Sep;28(2):242-6. PMID:10897089

13. Nobakht M, Dezhkam M. An epidemiological study of eating disorders in Iran. Int J Eat Disord. 2000 Nov;28(3):265-71. PMID:10942912 
14. Aoun A, Garcia FD, Mounzer C, Hlais S, Grigioni S, Honein K, et al. War stress may be another risk factor for eating disorders in civilians: a study in Lebanese university students. Gen Hosp Psychiatry. 2013 Jul-Aug;35(4):393-7. PMID:23557894

15. King M. The epidemiology of eating disorders. Epidemiol Psichiatr Soc. 1998 Jan-Apr;7(1):32-41. PMID:9658680

16. Garner DM, Garfinkel PE. The Eating Attitudes Test: an index of the symptoms of anorexia nervosa. Psychol Med. 1979 May;9(2):273-9. PMID:472072

17. Williams P, Hand D, Tarnopolsky A. The problem of screening for uncommon disorders - a comment on the Eating Attitudes Test. Psychol Med. 1982 May;12(2):431-4. PMID:7100366

18. Garner D, Olmstead M, Polivy J. Development and validation of a multidimensional eating disorder inventory for anorexia nervosa and bulimia. Int J Eat Disord. 1983;2:15-34.

19. Fairburn C, Cooper Z. The Eating Disorder Examination. In Fairburn CG, Wilson GT, editors. Binge eating: nature, assessment and treatment, 12th ed. Guilford (UK): The Guilford Press; 1993:317-60

20. Henderson M, Freeman CP. A self-rating scale for bulimia. The 'BITE'. Br J Psychiatry. 1987 Jan;150:18-24. PMID:3651670

21. Fairburn CG, Beglin SJ. Assessment of eating disorders: interview or self-report questionnaire? Int J Eat Disord. 1994 Dec;16(4):363-70. PMID:7866415

22. Garner M. Eating Disorder Inventory-3. Professional manual. Lutz (FL): Psychological Assessment Resources Inc.; 2004.

23. Morgan JF, Reid F, Lacey JH. The SCOFF questionnaire: assessment of a new screening tool for eating disorders. BMJ. 1999 Dec 4;319(7223):1467-8. PMID:10582927

24. Perry L, Morgan J, Reid F, Brunton J, O'Brien A, Luck A, et al. Screening for symptoms of eating disorders: reliability of the SCOFF screening tool with written compared to oral delivery. Int J Eat Disord. 2002 Dec;32(4):466-72. PMID:12386911

25. Muro-Sans P, Amador-Campos JA, Morgan JF. The SCOFF-C: psychometric properties of the Catalan version in a Spanish adolescent sample. J Psychosom Res. 2008 Jan;64(1):81-6. PMID:18158003

26. Lähteenmäki S, Aalto-Setälä T, Suokas JT, Saarni SE, Perälä J, Saarni SI, et al. Validation of the Finnish version of the SCOFF questionnaire among young adults aged 20 to 35 years. BMC Psychiatry. 2009;9:5. PMID:19200401

27. Garcia FD, Grigioni S, Chelali S, Meyrignac G, Thibaut F, Dechelotte P. Validation of the French version of SCOFF questionnaire for screening of eating disorders among adults. World J Biol Psychiatry. 2010 Oct;11(7):888-93. PMID:20509759

28. Siervo M, Boschi V, Papa A, Bellini O, Falconi C. Application of the SCOFF, Eating Attitude Test 26 (EAT 26) and Eating Inventory (TFEQ) questionnaires in young women seeking diet-therapy. Eat Weight Disord. 2005 Jun;10(2):76-82. PMID:16114220

29. Garcia-Campayo J, Sanz-Carrillo C, Ibañez JA, Lou S, Solano V, Alda M. Validation of the Spanish version of the SCOFF questionnaire for the screening of eating disorders in primary care. J Psychosom Res. 2005 Aug;59(2):51-5. PMID:16185998

30. Parker SC, Lyons J, Bonner J. Eating disorders in graduate students: exploring the SCOFF questionnaire as a simple screening tool. J Am Coll Health. 2005 Sep-Oct;54(2):103-7. PMID:16255322

31. Rosenberg L, Joseph L, Barkun A. Surgical arithmetic: epidemiological, statistical and outcome-based approach to surgical practice. Austin (TX): Landes Bioscience; 2004.

32. Mond JM, Myers TC, Crosby RD, Hay PJ, Rodgers B, Morgan JF, et al. Screening for eating disorders in primary care: EDEQ versus SCOFF. Behav Res Ther. 2008 May;46(5):612-22. PMID:18359005

33. Luck AJ, Morgan JF, Reid F, O'Brien A, Brunton J, Price C, et al. The SCOFF questionnaire and clinical interview for eating disorders in general practice: comparative study. BMJ. 2002 Oct 5;325(7367):755-6. PMID:12364305 